またTV 透視による位置決め（断層面の深度設定含 む）功遠隔操作により容易に行える．患者を移動するこ となく透視撮影から断層撮影へ移れるなど能率の著しい 向上および最良の条件時でのタイミング良い撮影が可能 となった。

\section{2/3インチ高圧集束形撮像管使用低雑音 $\mathrm{X}$ 線テレビ ジョン装置の実用化}

$$
\text { 日立メディコ柏工場 }
$$

○白木英成・加野岑夫

日立メディコ研究開発センター 池田 渾・石川 謙

2/3インチ撮影管を使用し，小形でありながら從来の1 インチ撮影管に匹敵する性能を備えたX線テレビシステ ムを実用化した，主な改良点は(1)テレビカメラの撮影管 を高圧集束タイプとして MTF を向上させ,低雑音 FET の 2 段構成プリアンプで $\mathrm{S} / \mathrm{N}$ を 6〜 $7 \mathrm{~dB}$ 改善した. (2) カメラコントローラについては $\gamma$ 補正回路で視覚に自 然な特性を保たせ，シェーディング補正を充分できるよ うにした。(3)モ二タのゲイン向上，ホーカスの安定化， ホワイトクリップを強化した他, 用途別切替スイッチを 内蔵し, 消化器用・循環器用の何れにも最適条件が得ら れる特性を持たせた。䠛床評価の結果, 画像の鮮明さ, 線量の低減化，ノイズの目立ちにくさなど好評を得た。

\section{座長集約}

当演題群は, 自動露出 1 題之 X-TV 3 題が含まれてい る. 演題421は, 胃部用面積補正型自動露出装置について, $\mathrm{Ba}$ ならびに直接X線の影響による問題解決について, 被覆面積に上る濃度補正機能を加え検討している。 また 透視手技上の寝台等の情報屯回路内に取り入れ，上りき めのてまかい制御を目的としている。乙の問題は，他の 発表に見られるW. フィルタとの補正組合せによってよ り良し制御ができると考えられ今後の検討が望まれる。 演題 422 -423亿, 同一の内容の発表である.乙れは従来 のオーバーチューブ型透視撮影台に断層機能を付加した あのである. この演題について，䉼層撮影時の自動露出 の有無についての質問（座長）に関しては，現在てれを 用いて無いととから今後の研究が望まれる。また発表の 内容についてであるが，従来ああったが，単なる新製品 の紹介では，乙の学会の研究発表として疑問を感ずる所 ああり, 特にメ一カ一の発表之重複する場合, その研究 の目的や研鑚の内容を盛込んで今後発表することが望ま 机る。

演題424は，X線 TV の撮影管についてであり，小形で 高性能なむのへの改良に妓力している. 今後 DF 用等で,
高性能画像がその装置の良し悪しを左右すると見られ， この目的にも良い撮像管の開発か望まれる。

今回自動露出装置に関する演題が少なかったが，現在 では, 自動露出装置が発生器の一部として考えられ, 単 独で考えることが無理になった感があり，受光部等の開 発や，他の組合せにより，良い効果を生み出すための研 究等, 今後の検討が望まれる.

\section{管理技術一 4 管理用測定器}

座長 高田卓雄

\section{5. 回帰分析法を用いたマイコンによる散乱線等線量 分布図の作成}

鳥取大学医学部附属病院放射線部

○平田吉春・山根武史・西尾 剛 松田敏裕・松下 愽・角原重利 遠藤健一

室内散乱線量の測定は，患者，そして稀に患者固定の ための付き添しの人，われわれ技師，特殊検查のために 室内にはいる医師等, これらの人達の被曝を低減および 管理するためにも重要な役目を果たしている，今回われ われは，距離による減衰を逆 2 乗計算値で，吸収による 減弱は，K值＝(測定值/逆 2 乗計算值）を回帰分析より 求め, $\mathrm{A}$ 点と $\mathrm{B}$ 点の間の吸収による減弱を $\mathrm{K}(\mathrm{A}) / \mathrm{K}(\mathrm{B})$ と いう比として求められるようにした。 そして測定点以外 の所の線量計算は逆 2 乗法則と, 乙の回帰分析より求め られたK值を用い，またすべての計算処理および室内散 乱線量等線量分布図作成を, マイクロコンピュータに行 わせ，短時間に様々な条件の分布図作成ができるように した。

\section{6. $\mathrm{X}$ 線撮影室内の散乱 $\mathrm{X}$ 線スペクトル解析}

自治医科大学 RI センター O菊地 透 自治医科大学付属病院 伊勢孝雄

病院の放射線作業者の被嚗源の大半は，X線撮影装置 からの散乱線および漏洩X線である. 今回, 高純度 $\mathrm{Ge}$ 半導体検出器を用いて, X線スペクトル解析を行い, と のような作業状況における個人モニタリングについて考 察した. その結果, 患者からの散乱線スペクトルは, 一 次 $\mathrm{X}$ 線の最大エネルギー上り $8 \sim 10 \%$ 程度低エネルギー 側にシフトする。また，作業者の被曝寄与の 8 割弱を示 める. 多重シャターからのスペクトルは, 散乱線乙漏洩 X線が同時に存在しており, 管電压 $100 \mathrm{kV}$ 以上では, 鉛の特性X線が支配的な影響をもつ。したがって，測定 器の使用および遮へい計算には, 各エネルギー成分を十 分に把握して行う必要があることを指摘した. 